\title{
Water Policy for Sustainable Management: A Review
}

\author{
Dereje Alemu Bekele ${ }^{1, ~ *}$, Solomon Kia Bona ${ }^{2}$, Hazhar Sami Haji ${ }^{3}$ \\ ${ }^{1}$ Assosa Agricultural Research Center, Ethiopian Institute of Agricultural Research, Addis Ababa, Ethiopia \\ ${ }^{2}$ Pharmacy Board of Sierra Leone, Freetown, Sierra Leone \\ ${ }^{3}$ Duhok Agricultural Company, Kurdistan, Iraq
}

Email address:

dalemu9@gmail.com (D. A. Bekele), solokbona607@gmail.com (S. K. Bona), hazhar.haji@gmail.com (H. S. Haji)

${ }^{*}$ Corresponding author

\section{To cite this article:}

Dereje Alemu Bekele, Solomon Kia Bona, Hazhar Sami Haji. Water Policy for Sustainable Management: A Review. International Journal of Applied Agricultural Sciences. Vol. 7, No. 3, 2021, pp. 110-118. doi: 10.11648/j.ijaas.20210703.11

Received: January 30, 2021; Accepted: May 19, 2021; Published: May 27, 2021

\begin{abstract}
Water is a fundamental need for life and societal growth. It is essential to meet personal and household needs, as well as for energy and industrial development, as well as to preserve critical water-dependent habitats and ecological services. Demand for the world's highly limited water supply is quickly growing, posing a threat to global food security and limiting its availability for food production. This research review addresses the increasing of global water use per year, global water policy for sustainable management, challenges, traits and opportunities with the objective of determining the best practice of water policy for the future generation. The world population increased from 2.77 billion to 7.794 billion since 1955 till end of 2020 with the growth rate of $1.88 \%$ to $1.05 \%$ respectively. The World Gross domestic product from 1960-2019 increased from 1.36 $\$$ trillion to $87.67 \$$ trillion. Due to increasing population, economic development and climate change the global freshwater use since 1900 by broad regional groupings indicate that: OECD nations (Organizations for Economic Cooperation and Development) uses approximately 20-25\%, BRICS countries (Brazil, Russia, India, China and South Africa) use the largest share at approximately $45 \%$ and the Rest of the World nations (ROW) use at 30-33\%. Thus, to achieve sustainable water management, best water policy should provide a multi-disciplinary and comprehensive approach that addresses scientific, environmental, economic, landscape aesthetics, societal, and cultural issues.
\end{abstract}

Keywords: GDP, Global Freshwater Use, Sustainable Water Management, Water Policy, Water Withdrawals

\section{Introduction}

Water is a fundamental need for life and societal growth. It is essential to meet personal and household needs, as well as for energy and industrial development, as well as to preserve critical water-dependent habitats and ecological services. It is the foundation of sustainable development as it is the common denominator of all global challenges: energy, food, health, peace and security, and poverty eradication [27]. Only 3\% of the Earth's water is fresh water, the remaining $97 \%$ is found in seas and oceans. While all lakes, rivers and swamps combined only account for a small fraction of $0.3 \%$ of the Earth's total freshwater reserves [24]. In this matter, both direct and simulated water (water contained in a product) is growing in demand for this fresh water, which is essential for life, due to growth of the world's population. In addition, in a world economy, water plays a major role in agriculture, in the domestic, industrial sector, fisheries, transportation aid, cooling, heating, and many sports activities, such as swimming, pleasure or other kinds of fun; (Leisure, Oil, natural gas, and products transported by boats via sea, rivers, lakes and canals, etc.). Overall, it is important for human life, socioeconomic growth, and sustainable environments.

Demand for the world's highly limited water supply is growing exponentially, putting its availability for food production in jeopardy and threatening global food security. Water supply management is critical for the international community to fulfil the promise of the 2030 Agenda for Sustainable Development [30]. Agriculture, which feeds a growing population, competes for this limited water source with commercial, household, and environmental uses. And as demand for water from all use's increases, groundwater is depleting, other water ecosystems are being contaminated and 
deteriorated, and finding new water supplies is becoming more expensive [3].

Water is particularly susceptible to contamination because it dissolves more contaminants than any other material on the planet. It is easily tainted by either point or non-point emission sources. Toxic compounds from fields, cities, and factories easily dissolve and combine with it, polluting the water. When rain rains and seeps deep into the soil, covering the cracks, crevices, and porous spaces of an aquifer (basically an underwater reservoir of water), it becomes freshwater, one of our least visible but most valuable natural resources. Both surface and groundwater get polluted when contaminants from pesticides and fertilizers to waste leached from landfills and septic systems that make their way into an aquifer, rendering it unsafe for human use. Contaminant removal from groundwater can be difficult, even impossible, and expensive. When an aquifer becomes poisoned, it can become unusable for decades, even thousands, of years. When it seeps into streams, reservoirs, and oceans, groundwater will disperse pollution far from the initial polluting source. Because of the enantio-selective biodegradation of chiral toxins, chiral pollution is a serious issue for our health and the environment. It is harmful to our culture and science. Because of the use of racemic agrochemicals, our economy has suffered greatly. Pesticides, polychloro biphenyls, polyaromatic hydrocarbons, brominated flame retardants, medications, and pharmaceuticals are the most well-known chiral contaminants [2]. Waterborne diseases, such as disease-causing bacteria and viruses derived from human and animal waste, are a significant source of sickness from polluted drinking water. Among the diseases spread by polluted water are cholera, giardia, and typhoid. Also in wealthy countries, unintended or illicit waste treatment facility leaks, as well as agricultural and municipal runoff, add toxic pathogens to rivers [1].

Water resource policy which encompasses the policy-making processes that affect the collection, preparation, use and disposal of water to support human uses and protect environmental quality study is very important. This water policy addresses four decisions namely; provision, use, disposal and sustainability decisions. The first decision was provision decisions; which includes; identification, access and preparation for use and distribution. Secondly, use decision which includes; direct human consumption, agriculture, industry and ecosystem protection. The third decision was disposal decisions that involves wastewater treatment and storm water /flood management. The last decision that should have to be addressed in water policy was sustainability decision issues, such as aquifer depletion, reservoir management and mineral buildup. Water policy, therefore shows us, how the policies created, executed and amended without influencing political boundaries with negotiation among multiple political entities such as; nations, states, etc. Though policy makers typically should adopt a set of best management practices (BMPs) to govern water management. When we say best management practices it will cover everything, from dam construction to wastewater treatment protocols.

The other way of achieving good water policy was through sustainable water management which is a critical component for sustainable development. For meeting of current water demand for all water users without impairing future supply best water policy is mandatory. In general, achieving sustainable water management necessitates a multidisciplinary and comprehensive approach that addresses technological, financial, economic, landscape aesthetic, societal, and cultural issues. Despite the fact that water is a prime natural resource, a fundamental human need, and a valuable global commodity, water resource preparation, growth, and management must be driven by global perspectives.

\section{The Importance of Studying Water Policy}

Is that possible to feed 8.1 billion populations in 2025 ? Or 10 billion populations in 2057? [26]. The answer is impossible unless, better water policy created, amended and executed for sustainable water management since water have big role specifically in the production of food and generally in economic development. According to various research findings, global water use is growing year after year due to increasing population, economic growth with changing use habits, intermittent and unpredictable availability, and climate change, which aggravates the situation of currently water-stressed regions and generates water stress in regions where water supplies are still plentiful today $[10,20]$.

\subsection{Population}

Table 1, indicated that the world population increased from 2.77 billion to 7.794 billion since 1955 till end of 2020 with the growth rate of $1.88 \%$ to $1.05 \%$ respectively. The yearly population percentage change increased at increasing rate from 1955 up to 1970, whereas from 1970 up to 2020 increased at decreasing rate. The density of population per kilometer square and urban population also increased from 1955 up to 2020 [26]. These increments of population in addition to other factors have impact on the demand of water for both direct consumption and virtual use. Due to this the water policy also affected to some extent that need amendments to bring water resource sustainability on the globe.

Figure 1, also confirmed that the Population of the world is currently (2020) growing at a rate of around $1.05 \%$ per year (down from $1.08 \%$ in $2019,1.10 \%$ in 2018 , and $1.12 \%$ in 2017). The average population growth is currently projected at 81 million per year. 
Table 1. World population (2020 and historical).

\begin{tabular}{lllllll}
\hline Year & World Population & Yearly Change & Net Change & Density $\left(\mathbf{P} / \mathbf{K m}^{2}\right)$ & Urban Population & Urban Population \% \\
\hline 2020 & $7,794,798,739$ & $1.05 \%$ & $81,330,639$ & 52 & $4,378,993,944$ & $56 \%$ \\
2019 & $7,713,468,100$ & $1.08 \%$ & $82,377,060$ & 52 & $4,299,438,618$ & $56 \%$ \\
2018 & $7,631,091,040$ & $1.10 \%$ & $83,232,115$ & 51 & $4,219,817,318$ & $55 \%$ \\
2017 & $7,547,858,925$ & $1.12 \%$ & $83,836,876$ & 51 & $4,140,188,594$ & $55 \%$ \\
2016 & $7,464,022,049$ & $1.14 \%$ & $84,224,910$ & 50 & $4,060,652,683$ & $54 \%$ \\
2015 & $7,379,797,139$ & $1.16 \%$ & $84,506,374$ & 50 & $3,981,497,663$ & $54 \%$ \\
2014 & $7,295,290,765$ & $1.17 \%$ & $84,708,789$ & 49 & $3,902,831,934$ & $53 \%$ \\
2013 & $7,210,581,976$ & $1.19 \%$ & $84,753,917$ & 48 & $3,824,990,329$ & $53 \%$ \\
2012 & $7,125,828,059$ & $1.20 \%$ & $84,633,758$ & 48 & $3,747,842,586$ & $53 \%$ \\
2011 & $7,041,194,301$ & $1.21 \%$ & $84,370,698$ & 47 & $3,671,423,872$ & $52 \%$ \\
2010 & $6,956,823,603$ & $1.22 \%$ & $84,056,510$ & 47 & $3,594,868,146$ & $52 \%$ \\
2005 & $6,541,907,027$ & $1.25 \%$ & $80,747,638$ & 44 & $3,215,905,863$ & $49 \%$ \\
2000 & $6,143,493,823$ & $1.31 \%$ & $79,254,768$ & 41 & $2,868,307,513$ & $47 \%$ \\
1995 & $5,744,212,979$ & $1.43 \%$ & $81,062,552$ & 39 & $2,575,505,235$ & $45 \%$ \\
1990 & $5,327,231,061$ & $1.71 \%$ & $89,789,503$ & 36 & $2,290,228,096$ & $43 \%$ \\
1985 & $4,870,921,740$ & $1.82 \%$ & $86,910,119$ & 33 & $2,007,939,063$ & $41 \%$ \\
1980 & $4,458,003,514$ & $1.77 \%$ & $77,497,414$ & 30 & $1,754,201,029$ & $39 \%$ \\
1975 & $4,079,480,606$ & $1.89 \%$ & $75,686,434$ & 27 & $1,538,624,994$ & $38 \%$ \\
1970 & $3,700,437,046$ & $2.06 \%$ & $74,756,419$ & 25 & $1,354,215,496$ & $37 \%$ \\
1965 & $3,339,583,597$ & $2.00 \%$ & $65,605,259$ & 22 & $1,188,469,224$ & $36 \%$ \\
1960 & $3,034,949,748$ & $1.86 \%$ & $55,373,563$ & 20 & $1,023,845,517$ & $34 \%$ \\
1955 & $2,773,019,936$ & $1.77 \%$ & $48,173,195$ & 19 & $877,008,842$ & $32 \%$ \\
\hline
\end{tabular}

Source: UN-DESA, Population Division, 2020

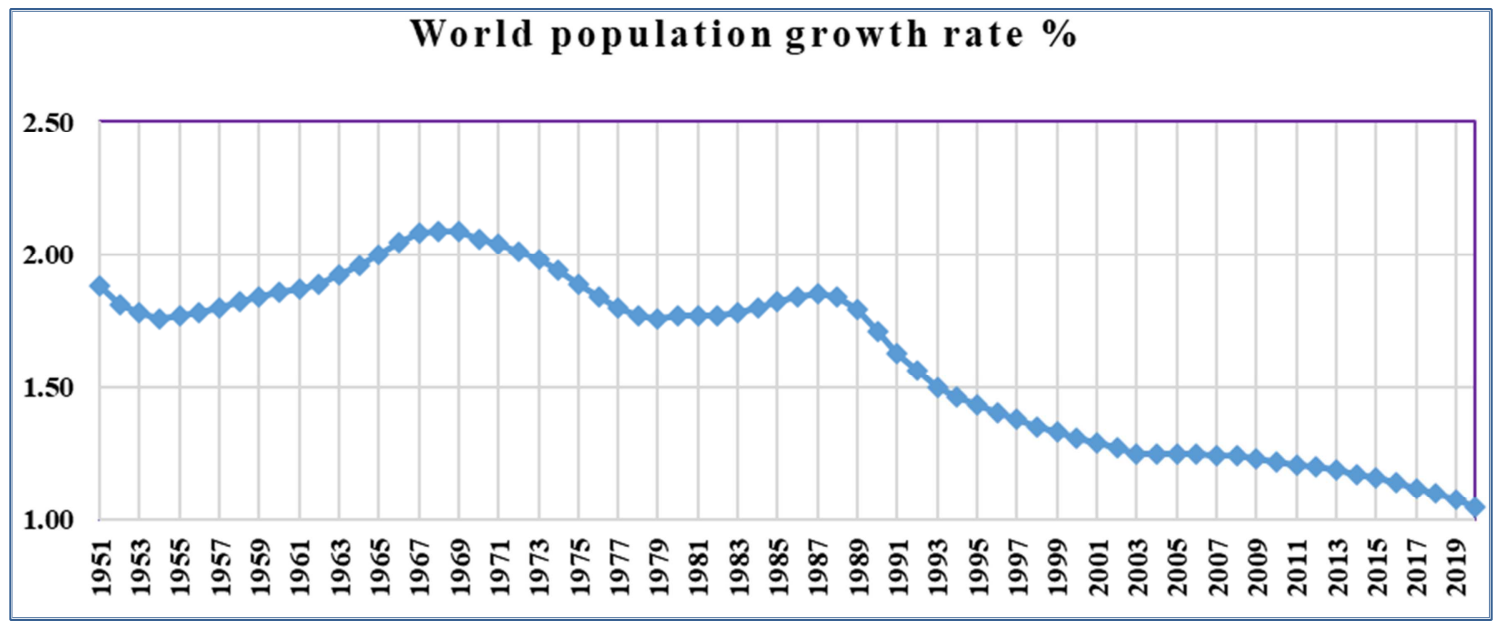

Source: UN-DESA, Population Division, 2020

Figure 1. World Population Yearly growth rate percentage.

Therefore, in the 21st Century the world's population will remain growing, but at a much slower pace than in the past. World population has doubled (100\% increase) in 40 years from 1960 (3 billion) to 2000 (6.1 billion). It is now estimated that it will take another nearly 40 years to increase by another $50 \%$ to become 9.1 billion by 2040 as shown in Table 2 . The latest world population projections indicate that world population will reach 10 billion persons in the year 2057 [26].

Table 2. World population forecast (2020-2100).

\begin{tabular}{|c|c|c|c|c|c|c|c|c|}
\hline Year & Population & $\begin{array}{l}\text { Yearly \% } \\
\text { Change }\end{array}$ & Yearly Change & $\begin{array}{l}\text { Median } \\
\text { Age }\end{array}$ & $\begin{array}{l}\text { Fertility } \\
\text { Rate }\end{array}$ & $\begin{array}{l}\text { Density } \\
\left(\mathbf{P} / \mathrm{Km}^{2}\right)\end{array}$ & $\begin{array}{l}\text { Urban } \\
\text { Pop \% }\end{array}$ & Urban Population \\
\hline 2100 & $10,874,902,318$ & $0.03 \%$ & $3,090,840$ & 73 & N. A. & N. A. & N. A. & N. A. \\
\hline 2057 & $10,038,871,455$ & $0.40 \%$ & $39,793,139$ & 67 & N. A. & N. A. & N. A. & N. A. \\
\hline 2050 & $9,735,033,990$ & $0.53 \%$ & $50,646,143$ & 36 & 2.95 & 65 & 68.60 & $6,679,756,162$ \\
\hline 2045 & $9,481,803,274$ & $0.61 \%$ & $56,591,207$ & 35 & 2.85 & 64 & 66.60 & $6,312,544,819$ \\
\hline 2040 & $9,198,847,240$ & $0.69 \%$ & $62,264,605$ & 35 & 2.77 & 62 & 64.60 & $5,938,249,026$ \\
\hline 2035 & $8,887,524,213$ & $0.78 \%$ & $67,807,363$ & 34 & 2.7 & 60 & 62.50 & $5,555,833,477$ \\
\hline 2025 & $8,184,437,460$ & $0.98 \%$ & $77,927,744$ & 32 & 2.54 & 55 & 58.30 & $4,774,646,303$ \\
\hline 2020 & $7,794,798,739$ & $1.10 \%$ & $83,000,320$ & 31 & 2.47 & 52 & 56.20 & $4,378,993,944$ \\
\hline
\end{tabular}

Source: UN-DESA, Population Division, 2020 
From Table 2 it can be seen that the world population projection 2020 to 2100 will increase from 7.79 billion to 10.87 billion with the yearly percentage change of increasing at decreasing rate. The median age, Fertility rate, density of population per kilometer square and urban population is also increasing from 2020 up 2100 according to the population projection [26].

As indicated in Table 3, World population by region wise, the largest population was found in Asia with 4.6 billion which was $59.50 \%$ of world share and followed by Africa with
1.34 billion or $17.20 \%$ of world share, the continent that rural population lags behind global progress to provide safe drinking water to everyone [21], whereas Oceania was the least populated region with $0.50 \%$. The yearly percentage change was high in Africa with $2.49 \%$ and less in Europe with $0.06 \%$. The higher density of population per kilometer square found in Asia by 150 people per kilometer square. Europe was the oldest populated region with Median age of 43 and Africa was the youngest population with the median age of 20 .

Table 3. World Population by region.

\begin{tabular}{|c|c|c|c|c|c|c|c|c|c|c|}
\hline S. $\mathbf{N}$ & Region & $\begin{array}{l}\text { Population } \\
-2020 \\
\end{array}$ & $\begin{array}{l}\text { Yearly } \\
\text { Change }\end{array}$ & Net Change & $\begin{array}{l}\text { Density } \\
\left(\mathbf{P} / \mathbf{K m}^{2}\right) \\
\end{array}$ & $\begin{array}{l}\text { Land Area } \\
\left(\mathrm{Km}^{2}\right)\end{array}$ & $\begin{array}{l}\text { Migrants } \\
\text { (net) }\end{array}$ & $\begin{array}{l}\text { Fert. } \\
\text { Rate }\end{array}$ & $\begin{array}{l}\text { Med. } \\
\text { Age } \\
\end{array}$ & $\begin{array}{l}\text { World } \\
\text { Share } \\
\end{array}$ \\
\hline 1 & Asia & $4,641,054,775$ & $0.86 \%$ & $39,683,577$ & 150 & $31,033,131$ & $-1,729,112$ & 2.2 & 32 & $59.50 \%$ \\
\hline 2 & Africa & $1,340,598,147$ & $2.49 \%$ & $32,533,952$ & 45 & $29,648,481$ & $-463,024$ & 4.4 & 20 & $17.20 \%$ \\
\hline 3 & Europe & $747,636,026$ & $0.06 \%$ & 453,275 & 34 & $22,134,900$ & $1,361,011$ & 1.6 & 43 & $9.60 \%$ \\
\hline 4 & Latin America & $653,962,331$ & $0.90 \%$ & $5,841,374$ & 32 & $20,139,378$ & $-521,499$ & 2 & 31 & $8.40 \%$ \\
\hline 5 & N. America & $368,869,647$ & $0.62 \%$ & $2,268,683$ & 20 & $18,651,660$ & $1,196,400$ & 1.8 & 39 & $4.70 \%$ \\
\hline 6 & Oceania & $42,677,813$ & $1.31 \%$ & 549,778 & 5 & $8,486,460$ & 156,226 & 2.4 & 33 & $0.50 \%$ \\
\hline
\end{tabular}

Source: UN-DESA, Population Division, 2020

\subsection{Economic Development}

The World Gross Domestic Product (GDP) of an economy which measures total production were increasing from time with shifting of consumption pattern. More precisely, it is the monetary value of all goods and services produced within a country or region in a specific time period [29].

Figure 2, indicated that the World Gross domestic product from 1960-2019 increased from \$ 1.36 trillion to $\$ 87.67$ trillion. According to the world economic outlook [12, 14], global growth is expected to be $-4,9 \%$ by $2020,1.9$ percentage points below April 2020. In the first half of 2020, COVID-19 has a more adverse effect on the operation than expected and it is estimated that the rebound will be progressive than predicted [13]. Global growth of 5.4 percent is expected in 2021. Overall, GDP will be about $80 \%$ below the pre-COVID-19 forecasts of January 2020, which will leave GDP around 2021. The adverse consequences for low-income households are especially acute, threatening major progress towards poverty reduction in the world since the 1990s.

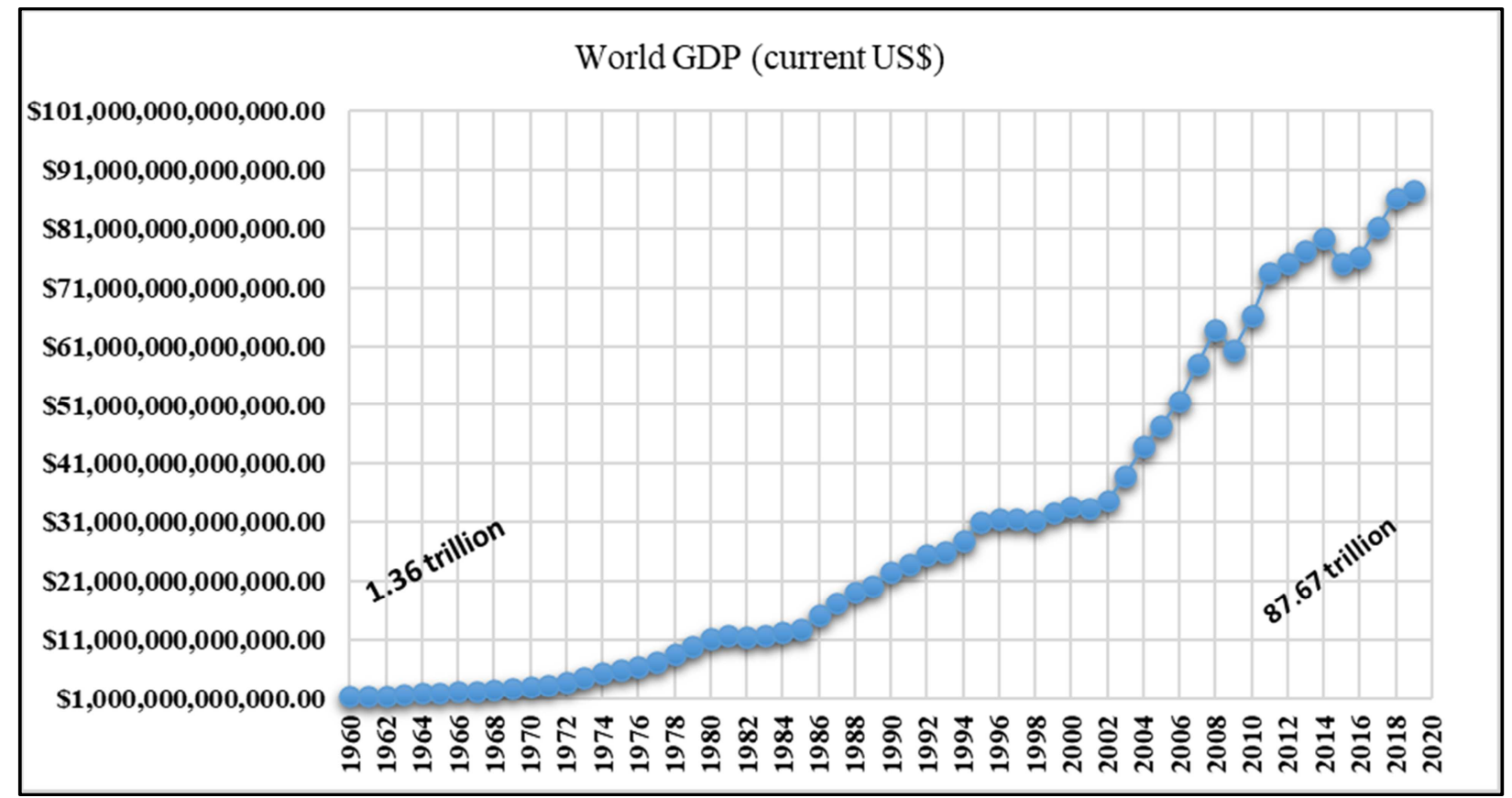

Source; World Bank, 2020

Figure 2. World GDP (current US\$) 1960-2020. 


\subsection{Climate Change}

Human action was the major driving force in the industrial age for increased global temperatures, with natural factors adding variation, as seen in Figure 3, as measured temperature from NASA, against the typical pre-industrial baseline of 1850-1900.

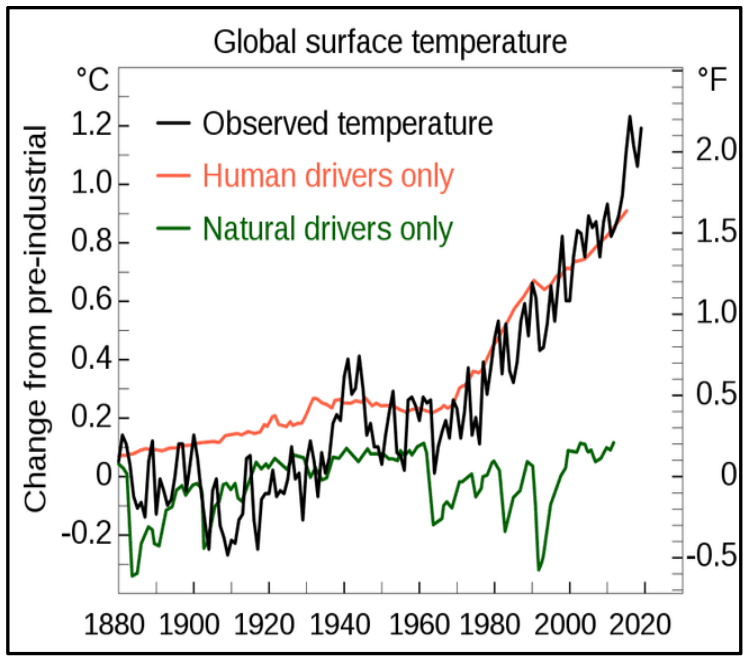

Source; WMO, 2020

Figure 3. Global Surface Temperature, World Meteorological Organization.

In 2018, the concentrations of $\mathrm{CO}_{2}$ and methane had increased by about $45 \%$ and $160 \%$, respectively, since 1750 [28].

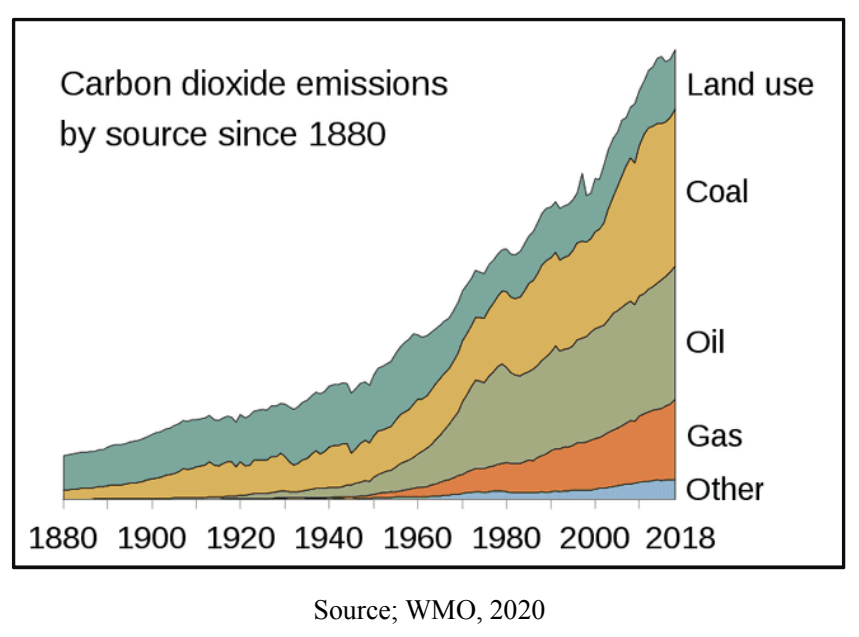

Figure 4. Carbon dioxide emissions by source since 1880.

Shared socioeconomic pathways are being established by the Intergovernmental Panel on Climate Change (IPCC). Shared SSPs are the predicted world-wide socio-economic shifts scenarios to 2100 [15].

They are used to derive greenhouse gas emissions scenarios with different climate policies. The scenarios are:

SSP1: Sustainability (Taking the Green Road)

SSP2: Middle of the Road

SSP3: Regional Rivalry (A Rocky Road)

SSP4: Inequality (A Road divided)

SSP5: Fossil-fueled Development (Taking the Highway)

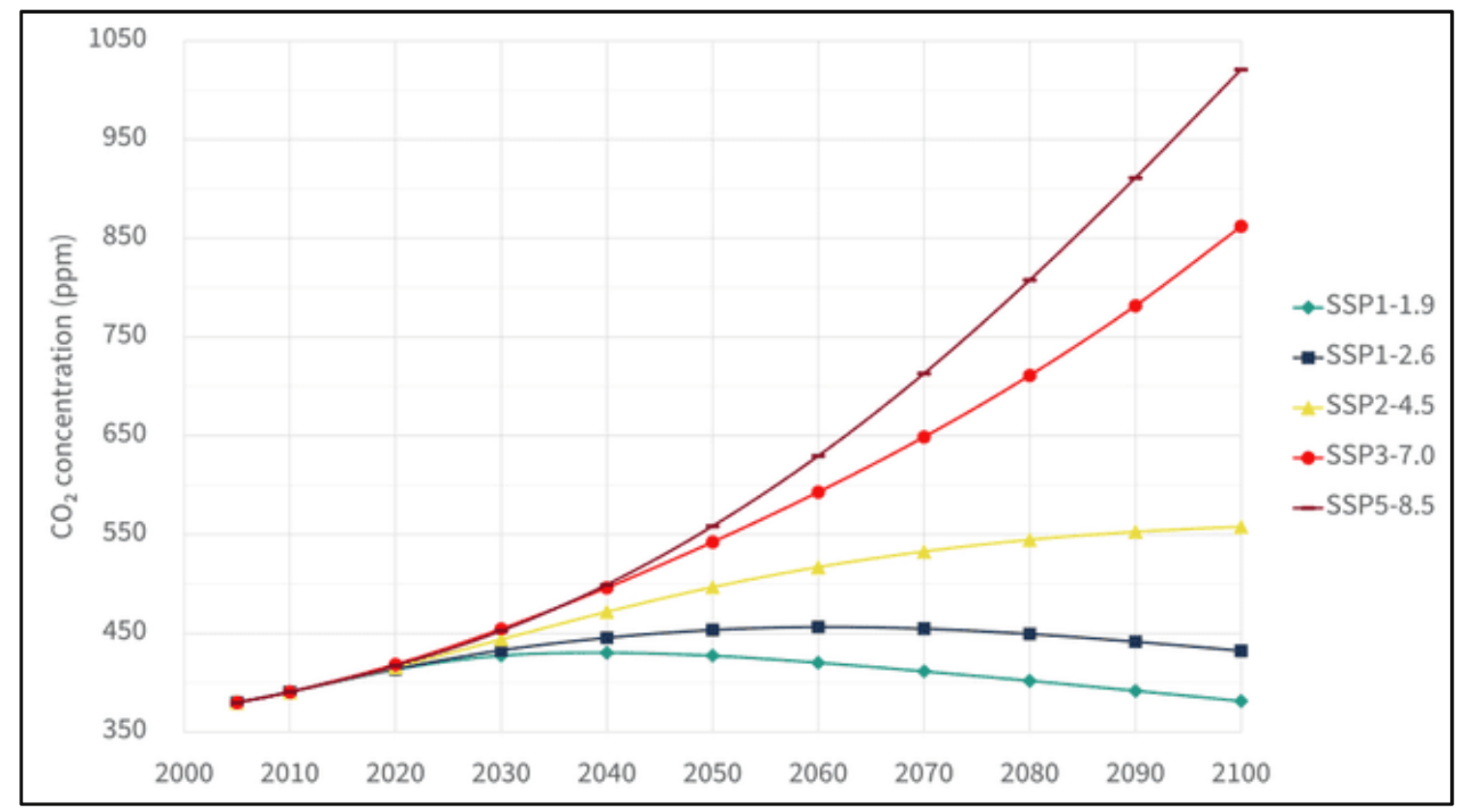

Source, IPCC MAGICC6, 2020

Figure 5. $\mathrm{CO}_{2}$ concentrations in the atmosphere over the course of the twenty-first century, as measured by SSP (MAGICC IPCC).

As indicated on Figure 5, Shared Socioeconomic Pathways, SSP1 up to SSP5 scenarios will vary with atmospheric $\mathrm{CO}_{2}$ concentrations by SSP across the 21st Century. Atmospheric
$\mathrm{CO}_{2}$ concentration from SSP1 to SSP5 will increase if current impact of human and natural drivers is aggravating [16]. 


\section{Water Resource, Use, and Policy for Sustainable Management on a Global Scale}

Figure 6, shows the Global freshwater use since 1900 by broad regional groupings were;

OECD nations (Organizations for Economic for cooperation and development, uses approximately 20-25\%.

BRICS countries (Brazil, Russia, India, China and South Africa) use the largest share at approximately $45 \%$.

Rest of the World (ROW) nations use at 30-33\% [11].

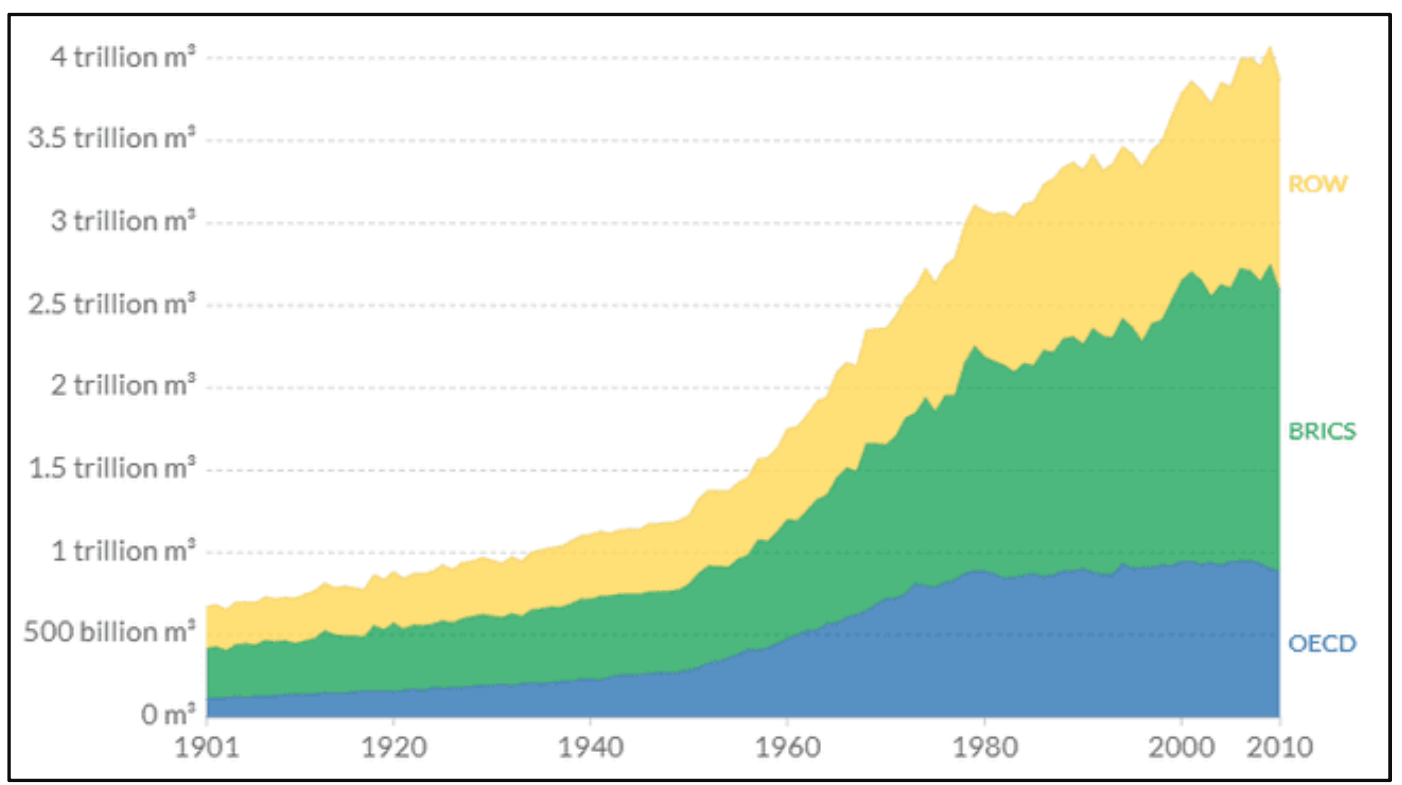

Source; Global International Geosphere-Biosphere Programme, 2020

Figure 6. Global fresh water use.

The 2018 edition of the United Nations (UN) World Water Development Report (WWDR) has provided an update on the present trends of clean water availability and future expectations [25]. The security of water is still at stake for many and the problem will worsen in the coming decades, as the ability of a public to guarantee sustainable access to sufficient amounts of water of reasonable consistency. In the world today with 7.7 billion people clean water shortage is a big problem. The water system pressure would rise by 2050 if the world's population is between 9.4 billion and 10.2 billion people, an increase of 22 to 34 percent. The pressure would be exacerbated by uneven demographic growth in many non-local resources sectors (Vide Figure 7). The majority of this population increase is projected to occur in developing countries, first in Africa and then in Asia, where safe water shortage is already a big problem [7, 22].

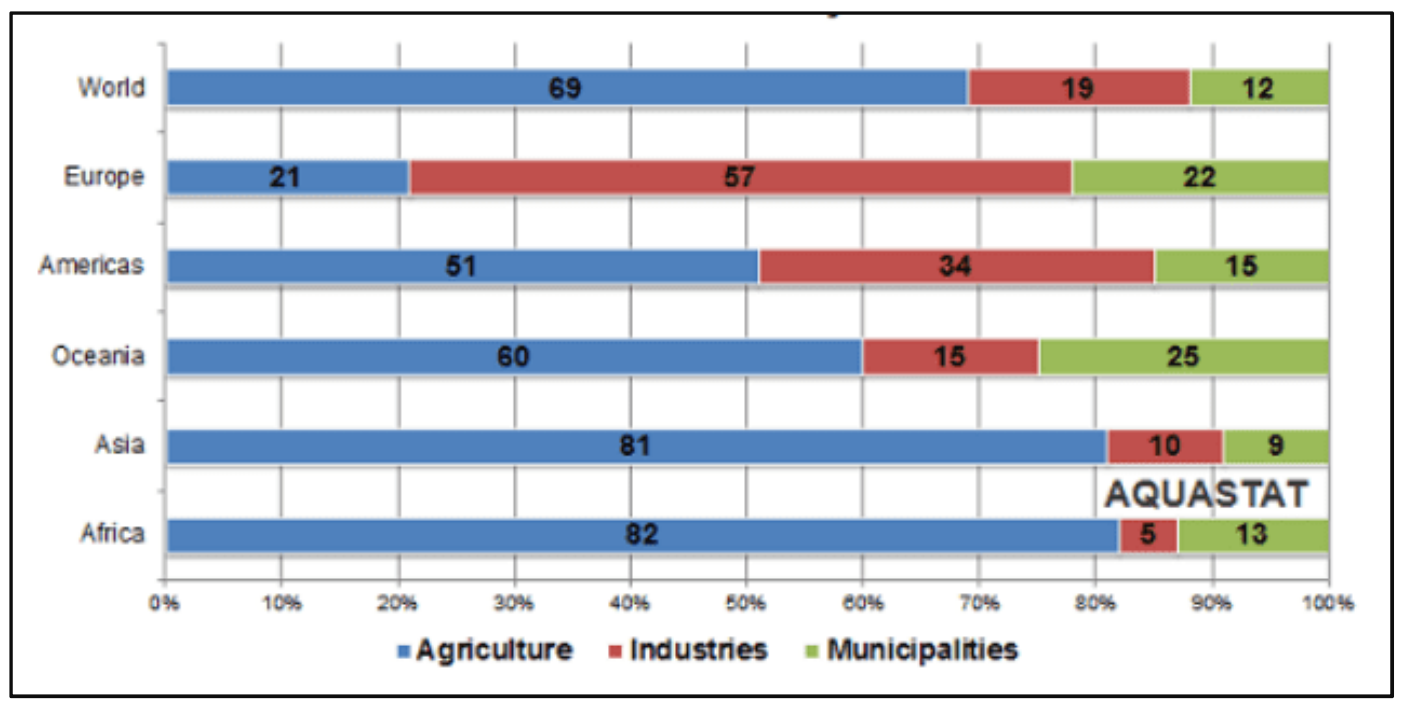

Source; AQUASTAT (FAO), 2020.

Figure 7. Water withdrawal ratios by continent. 


\subsection{Global Water Policy for Sustainable Management}

Sustainable Water Management and Sustainable Development Integration: Sustainable development and sustainable water management are linked to the water development needs. Water is a basic need for human life and well-being, so adequate water conservation is a way to boost food production, alleviate hunger, and prevent water-borne diseases.

Urban Water Development: Access to drinking water for safe and productive development is one of the most significant prerequisites. Water has an integral connection with socio-economic growth. A wider implementation of water re-use and Green Building Policies is part of sustainable urban water resources [8, 9, 19].

Agricultural Water Development: Sustainable agricultural water management by increasing irrigation productivity through improvements to technical, managerial, institutional, and agronomic methods [18, 23].

In the agriculture sector, there are strong possibilities to improve water productivity.

1) Better allocation of water and better performance in application.

2) Security of the environment

3) Environmental sustainability assessment is also required in conjunction with ecosystem services growth planning. "Poverty reduction strategies do not cause more water depletion or environmental roles and utilities" [17].

Millennium Development Goals for sustainable management

1) Eradicate extreme poverty and hunger; (Halving the proportion of people living on less than $\$ 1$ a day and halving malnutrition).

2) Accomplish primary universal education; (Ensuring that all children are able to complete primary education).

3) Promote gender equality and empower women; (Eliminating gender disparity in primary and secondary schooling, preferably by 2005 and no later than 2015.

4) Reduce child mortality; (Cutting the under-five death rate by two-thirds).

5) Enhance the wellbeing of mothers; (Reducing the maternal mortality rate by three-quarters).

6) Combat HIV/AIDS, malaria, and other diseases; (halt and begin to reverse HIV/AIDS and other diseases).

7) Ensure environmental sustainability; (Cutting by half the proportion of people without sustainable access to safe drinking water and sanitation).

8) Developing a sustainable growth partnership; (Reforming aid and trade with special treatment for the poorest countries).

The Sustainable Development Agenda for 2030 and its 17 Sustainable Development Objectives (SDGs) focus heavily on better water management. Social, economic and environmental, as well as important aspects related to peace, justice and effective institutions will be considered $[4,5]$. The international community must manage water resources if the 2030 Agenda for Sustainable Development is to be realized. Water is the foundation of sustainable development as it is the common denominator of all global challenges: energy, food, health, peace $\&$ security, and poverty eradication $[6,27]$.

\subsection{Global Sustainable Development Goals on Water}

Goal 1: achieve, by 2030, universal access to safe drinking water and sanitation for all.

Goal 2: By 2030, decrease water usage in agricultural irrigation by $20 \%$, commercial water uses by $20 \%$, and domestic water use by $15 \%$, and raise water productivity in all sectors by $50 \%$, by implementing a water demand management strategy, fewer water-demanding crops, water-saving technology, and increasing safe wastewater reuse.

Goal 3: by 2030 , increase by $50 \%$ the number of countries that have adopted and implemented policies and programmes for the public registration of water rights.

Goal 4: by 2030, reduce water pollution from main sources by $30 \%$ at the country level this target aims to reduce freshwater pollution by human activities by reducing the emissions at the source of the discharge.

\section{Challenges, Traits and Opportunities}

Main challenges

1) Poor resource management.

2) Corruption.

3) Inappropriate institutional arrangements.

4) Bureaucratic inertia.

5) Insufficient human capacity.

6) Shortages of finances for investments.

7) Undermine the effective governance of water.

Traits to

1) Access, quality and quantity of water in order to meet basic human needs;

2) Energy, food, sanitation, peace and stability, and poverty alleviation.

3) Sustainable management of water resources.

4) Ecosystem and human health

Opportunities

1) Resource endowment identification,

2) Maintain a balance between conflicting social, fiscal, and environmental demands for ocean resources.

3) A balance of timely policy interventions and more research-based policies.

4) Local, regional and global perspective

5) Prospects and challenges of multi-disciplinary research, science to fill knowledge gaps

6) Coordination between water policy and specific sector policies (e.g., agriculture, energy).

7) Increase water use efficiency and improving water allocation. 
8) Fight against corruption, inappropriate institutional arrangements and Bureaucratic inertia

9) As local demand for water exceeds availability in many areas, efficient regulation of limited water supplies would be critical to ensuring water stability, allocating water resources equally, and resolving water-related disputes.

10) In Water policy, Water law should have to be set properly because, landowners have the right to use as much of the water beneath their land as they want without any regulation or control.

11) Follow better water policy through best water management practices and measurement, because we don't have plan B.

\section{Conclusion}

Water is not only about development; it is a fundamental human right that is critical to global peace and stability. Addressing the water crisis is not a problem to be taken lightly. We must rise to this challenge if we are to leave behind a world that future generations can live in.

Planning, development and management of water resources need to be governed by common integrated perspective considering local, regional, State, national and international context having an environmentally sound basis, keeping in view the human, social and economic needs.

The impact of climate change on water resources availability must be factored into water management related decisions. While sustainable water management of urban, agricultural, and environmental systems is critical to long-term growth and may vary depending on geography and economic capacities, all regions should manage water supplies in a way that promotes long-term social, economic, and environmental development. We must calculate the volume of water that can be used without causing harm to other consumers or the environment's eco-systems.

Water-scarce countries can limit the export of comparatively water-intensive goods in order to discourage vast amounts of water from being diverted to other regions of the world. In general water policy needs multidisciplinary and holistic approach to bring water management sustainability in the long run.

Promotion of water use efficiency; improvement of water quality services through enhanced role of the private sector.

Rationalization of water management bodies. Restructuring of the federal water government, reorganization of the legislature, and corporatization of public-sector institutions

Water resource conservation and sustainable use; environmental preservation

Decentralized water administration focused on river basins; privatization and cost recovery; cross-sectoral analysis; production of regional water supplies.

In general, Water policy should focus on water productivity. Given the constraints on increasing the availability of utilizable water resources and increased variability of supplies as a result of climate change, meeting future needs would be more dependent on demand management, which must be prioritized, especially through the development of an agricultural system that conserves water while maximizing value from water and bringing in maximum efficiency in use.

\section{References}

[1] Ahmad J, Naeem S, Ahmad M, Usman ARA, Al-Wabel MI, 2019. A critical review on organic micropollutants contamination in wastewater and removal through carbon nanotubes $J$ Environ Manage doi: 10.1016/j.jenvman.2019.05.152.

[2] Al Arsh Basheer, 2018. Chemical chiral pollution: Impact on the society and science and need of the regulations in the $21^{\text {st }}$ century, Chirality 2018 Apr; 30 (4): 402-406.

[3] Alberto Boretti and Lorenzo Rosa, 2019. Reassessing the projections of the World Water Development Report, npj Clean Water 2: 15; https://doi.org/10.1038/s41545-019-0039-9.

[4] Anik et al, 2016. Achieving Sustainable Development Goals from a Water Perspective, journal Frontiers in Environmental Science, doi: 10.3389/fenvs.2016.00064.

[5] Animesh. et al, 2016. Measuring global water security towards sustainable development goals, Environ. Res. Lett. 11 124015, doi: $10.1088 / 1748-9326 / 11 / 12 / 124015$.

[6] Annie et al, 2018. SDG 14: Life Below Water: A review of research needs", Stockholm Environment Institute, Stockholm.

[7] AQUASTAT - FAO's Global Information System on Water and Agriculture.

[8] Bowen Feng et al, 2020. Planning of Food-Energy-Water-Waste (FEW2) nexus for sustainable development, BMC Chemical Engineering, https://doi.org/10.1186/s42480-020-0027-3.

[9] Cecilia Tortajada, 2020. Contributions of recycled wastewater to clean water and sanitation Sustainable Development Goals, npj Clean Water 3: 22; https://doi.org/10.1038/s41545-020-0069-3.

[10] David Butler et al, 2016. Reliable, resilient and sustainable water management: The Safe \& SuRe approach. Global Challenges open access. doi: 10.1002/chir.22808.

[11] Global International Geosphere-Biosphere Programme, 2020. http://www.igbp.net (Accessed $4^{\text {th }}$ September 2020).

[12] Global Water Outlook to 2025 - International Food Policy Research Institute (IFPRI) and the International Water Management Institute (IWMI).

[13] Helen Lambert, 2020. COVID-19 as a global challenge: towards an inclusive and sustainable future, Published Online, https://doi.org/10.1016/S2542-5196(20)30168-6.

[14] IMF, 2020, World Economic Outlook Reports, https://www.imf.org/en (Accessed 16 October, 2020).

[15] Imran Ali and C. K. Jain, 1998. Groundwater contamination and health hazards by some of the most commonly used pesticides, Current Science Vol. 75, No. 10 (25 November 1998), pp. 1011-1014. Intergovernmental panel on climate change, 2020. https://www.ipcc.ch (Accessed $5^{\text {th }}$ August 2020) 
[16] Joyeeta et al, 2013. Policymakers' Reflections on Water Governance Issues, Ecology and Society 18 (1): 35. http://dx.doi.org/10.5751/ES-05086-180135.

[17] Kerry Black and Edward McBean, 2017. Analysis of challenges and opportunities to meaningful Indigenous engagement in sustainable water and wastewater management, Water Policy 19 709-723.

[18] Lan Thompson, 2013. The role of technology in achieving water security, Phil Trans $R$ Soc A 371: 20120418. http://dx.doi.org/10.1098/rsta.2012.0418.

[19] Peiyue Li and Hui Qian, 2018. Water resources research to support a sustainable China, International Journal of Water Resources Development, 2018 VOL. 34, NO. 3, 327336https://doi.org/10.1080/07900627.2018.1452723.

[20] Reniko et al, 2019. Sustainable Water Resources Management: Issues and Principles of Water Governance in the Okavango Delta, Botswana, International Journal of Rural Management 15 (2) 198-217.

[21] Rob Hope et al, 2020. Rethinking the economics of rural water in Africa, Oxford Review of Economic Policy, Volume 36, Number 1, pp. 171-190.

[22] Rosa et al, 2020. Global agricultural economic water scarcity, science advances; 6: eaaz6031 29.
[23] U.S. Geological 2020. http://water.usgs.gov/edu/gallery/watercyclekids/earth-water-d istribution.html (Accessed 10 $0^{\text {th }}$ July 2020).

[24] United Nations (UN) World Water Development Report (WWDR), https://en.unesco.org/themes/water-security/wwap/wwdr (Accessed 12 ${ }^{\text {th }}$ November 2020).

[25] United Nations Population Division of the Department of Economic and Social Affairs (Accessed $31^{\text {th }}$ December 2020).

[26] UN-Water (United Nation Water), 2020. https://www.unwater.org (Accessed $10^{\text {th }}$ October 2020).

[27] WMO, World meteorological organization, 2020. https://public.wmo.int/en (Accessed $13^{\text {th }}$ September 2020).

[28] World bank, 2020. https://www.un.org/millenniumgoal, https://www.undp.org/content/undp/en/home/sustainable-devel opment-goals (Accessed $17^{\text {th }}$ October 2020).

[29] World Water Council, 2020. https://www.worldwatercouncil.org/en (Accessed $8^{\text {th }}$ August 2020).

[30] UNESCO WWAP, 2020. Water and Agenda 2030 | United Nations Educational, Scientific and Cultural Organization (unesco.org)(Accessed $10^{\text {th }}$ September 2020). 